\title{
Communication Technology Use by Caregivers of Adolescents With Mental Health Issues: Systematic Review
}

Ronelle Jansen, BSocSc, MSocSc, MCur; Marianne Reid, BCur, MSocSc, PhD

School of Nursing, Faculty of Health Science, University of the Free State, Bloemfontein, South Africa

Corresponding Author:

Ronelle Jansen, BSocSc, MSocSc, MCur

School of Nursing

Faculty of Health Science

University of the Free State

205 Nelson Mandela Drive

Bloemfontein, 9301

South Africa

Phone: 27825544731

Fax: 27514013435

Email: jansenro@ufs.ac.za

\begin{abstract}
Background: Caregivers of adolescents with mental health issues experience challenges that may result in the caregivers having a variety of unmet needs. There is a growing need to support these caregivers. Effective support to strengthen positive caregiving behavior in caregivers may address their challenges. Communication technologies offer novel opportunities to assist these caregivers and may contribute to strengthening caregiver behavior. However, little is known about the use of communication technologies among caregivers of adolescents with mental health issues.
\end{abstract}

Objective: The study aimed to answer the question: "What is the best evidence available to strengthen positive behavior of caregivers of adolescents with mental health issues using communication technology."

Methods: A systematic review of articles published between January 2007 and August 2018 was conducted. Searches included articles of multiple study designs from EBSCO Host and Scopus platforms with prespecified eligibility criteria. Methodological quality was evaluated using the applicable Critical Appraisal Skills Programme and Joanna Briggs Institute assessment tools.

Results: The search yielded 1746 articles. Altogether, 5 articles met the eligibility criteria and were included in the review for data synthesis. Data analysis and synthesis identified three thematic conclusions reflecting the types of communication technologies used, caregivers as the target population, and strengthening of positive behavior through determinants of the Integrated Model of Behavior Prediction.

Conclusions: The review reported the usefulness of communication technology by caregivers. Caregivers also demonstrated improvement in self-efficacy, knowledge, parent-child communication, and parental skills reflecting positive behavior. Although the use of communication technology is expanding as a supportive intervention to address caregivers' needs, the evidence for usefulness among caregivers of adolescents with mental health issues is still scarce. More research and information related to preferred methods of communication delivery among caregivers of adolescents is still needed.

(JMIR Mhealth Uhealth 2020;8(8):e13179) doi: $10.2196 / 13179$

\section{KEYWORDS}

caregiver; communication technology; adolescent; mental health issues; systematic review; self-efficacy, knowledge; parental skills; IMBP

\section{Introduction}

\section{Background}

"Nothing about me, without me" [1]
The caregiver landscape can be successfully supported through tailored solutions by acknowledging their unique challenges. Caregivers are largely invisible and are mostly underappreciated resources in community health services [2,3]. Caregivers are vital partners who contribute to health care provisioning in communities. They contribute to alleviating resource 
deficiencies and assist with task sharing in the health sector, despite not formally being part of the health sector [4-6] Regardless of this important contribution to health care delivery, caregivers receive minimal support from governments $[7,8]$. Globally, caregivers share a myriad of ongoing challenges and obstacles that are burdensome [2,9], often leading to unmet physical, psychological, and financial needs $[10,11]$.

Caregivers' own needs are mostly neglected because there is usually more attention focused on the care recipient or the family's needs [12]. It is thus vital to identify the unmet needs of the caregiver independently from those of the care recipient $[9,13]$. Unmet needs of caregivers merit more recognition and understanding in order to employ effective support to their prioritized needs [14]. Interventions for caregivers may be beneficial to address needs such as skills training, support, education, and access to resources $[15,16]$.

Fortunately, there is greater awareness of mediating interventions to support caregivers who are providing care for relatives with a chronic illness or disability [17]. Various interventions have been geared toward caregivers of persons presenting with dementia [14,18,19], cancer [20,21], HIV [22,23], chronic diseases [24-26], maternal and child health $[27,28]$, and long-term conditions in children [29,30]. Various authors [31,32] claim that there is limited research available that focuses on families caring for adolescents with mental health needs, while Cardamone-Breen et al [33] stated there is a scarcity of parental interventions to prevent them from internalizing the mental health issues of adolescents. Parentand family-focused interventions for child and adolescent mental health care are poorly represented in research [34-36]. Authors do not use similar terminology when referring to mental health issues, problems, illnesses, or conditions. This review will refer to mental health issues as a broad term for mental, emotional, and behavioral problems or disorders focusing on depression, anxiety, and substance use. Depression, anxiety, and substance use disorders are more common among adolescents [37-39]

Armoiry et al [40] reported equivocal findings regarding the use of communication technologies among families of young people with long-term conditions. Rodríquez-Meirinhos et al [31] also highlighted caregivers' need for education and information in preparation for caring for an adolescent with a mental illness. These authors [31] also established the necessity for dependable interventions to support families and community services to empower this group of caregivers.

Evidence-based supportive interventions that are flexible and developed according to the needs of caregivers may reduce caregiver burden and improve mental health caregiving [9]. Kuhn and Laird [41] stated that a combination of supportive interventions would be more useful for a diverse population, allowing tailored communication. Understanding caregivers' cultural context is important to develop a tailored intervention congruent to their specific needs [6,9,42]. Moreover, caregiver interventions should be sustainable [43], easily accessible [44], available [9], culturally, ethnically, and linguistically tailored [45], and caregiver-focused [46].

Literature suggests that communication technologies are arising as an acceptable intervention to assist caregivers of children and young people in the management of conditions [40]. Communication technologies terminology is labeled interchangeably in the literature but refers to computers, the internet, electronic health (eHealth), and mobile health (mHealth), including networks and media services to transmit information [47-50]. This taxonomy of communication technologies is often used simultaneously in the research of interventions reporting on various outcomes [51]. Combined communication technology interventions often result in effective health outcomes and are feasible substitutes for traditional health promotion approaches such as printed material [52,53]. Vergunst [54] also recommended that creative interventions need to be established for caregivers in resource-poor settings such as rural areas to bridge gaps in mental health service delivery for the individual, the family, and the community. Although communication technology interventions are potentially valuable to support caregivers of children with mental and behavioral problems [55], limited data are available even though it is a major public health concern [56]. The emergence of communication technologies to deliver training for caregivers is increasing and show promise in real-world setting [57].

Evidently, the usefulness of communication technology interventions for caregivers of adolescents with mental health issues differs. DeHoff et al [58] found that parents of children with special needs got support through an online social platform to accept and manage the child's condition. Another study disclosed that parents of youth with mental health problems seem to be positive about the use of computer-based therapies [59]. A web-based health promotion program utilized by adolescent girls and their mothers for drug use, among other conditions, resulted in positive health behavior changes [60]. The study by Russell et al [61] indicated a high satisfaction among parents of children with behavior problems when engaging in a computer-based education program.

The novelty of communication technologies in the management of psychiatric and mental health illnesses may be valuable to investigate [62]. According to Casale et al [63] and Robila [64], there is a need to support parents through interventions that provide resources to improve parenting, particularly in reducing adolescent behavioral and emotional problems. It would appear that communication technologies are beneficial in supporting caregivers in improving their skills, abilities, self-efficacy, and knowledge [65,66]. A review of caregivers caring for adolescents with developmental disabilities similarly highlighted the effect of tailored interventions to augment caregivers' self-efficacy, self-esteem, positive coping skills, and supportive social networks [67].

\section{Theoretical Framework}

The Integrative Model of Behavior Prediction (IMBP) endorses determinants such as attitudes, norms, and self-efficacy, by predicting behavior. Consequently, these determinants are based on underlying beliefs that, in turn, influence the intention to perform a specific behavior. Behavior may be challenged due to a lack of skills or environmental constraints $[68,69]$.

The IMBP guided this review in clarifying caregivers' behavioral intention for utilizing communication technologies by determining their belief, attitude, norms, self-efficacy, skills, 
environment, and intention. Behavioral intention can be predicted if the populations' beliefs, attitudes, norms, self-efficacy, skills, and environment are known [68,70,71]. To our knowledge, however, there have been no systematic efforts to synthesize evidence on the usefulness of communication technologies to strengthen positive behavior in caregivers of adolescents with mental health issues. Any positive response to a determinant was regarded as strengthening [71,72] of caregivers' behavior toward the adolescent.
The authors conducted a systematic review to collect and synthesize all evidence fitting the prespecified eligibility criteria. The authors sought to answer the following question based on the PICO format [73] (see Table 1 for the application of the PICO format): "What is the best evidence available to strengthen positive behavior of caregivers of adolescents with mental health issues using communication technology?" This paper provides a critical review and synthesis of the best available evidence about the use of communication technologies by caregivers of adolescents with mental health issues.

Table 1. Application of the PICO format.

\begin{tabular}{ll}
\hline PICO & Application \\
\hline Population & Caregivers of adolescents with mental health issues (Caregivers namely families, parents, sibling, carer, etc) \\
Intervention & Communication technology \\
Comparison & Routine communication technology \\
Outcome & IMBP $^{\mathrm{a}}$ determinants (beliefs, attitude, norms, self-efficacy, skills, environment, and intention) \\
\hline
\end{tabular}

aMBP: Integrated Model of Behavior Prediction.

\section{Methods}

\section{Design}

The authors undertook a systematic review that included multiple study designs [73-75]. This systematic review has been registered in PROSPERO (CRD42018094680) and was conducted according to PRISMA guidelines.

\section{Search Strategy}

A senior research librarian conducted a systematic search on electronic databases that covered articles published from January 1, 2007 to August 2, 2018. Databases from the EBSCO Host platform (PsycINFO, Academic Search Ultimate, MEDLINE with Full Text, Health Source: Nursing/Academic Edition, SocINDEX with Full Text, CINAHL with Full Text, ERIC, CAB Abstracts, MasterFILE Premier, Africa-Wide Information,
PsycARTICLES, OpenDissertations, Communication \& Mass Media Complete, Business Source Ultimate, SPORTDiscus with Full Text, Health Source - Consumer Edition, Humanities Source, EconLit with Full Text, GreenFILE) and the Scopus database were included. No language or study design restrictions were applied. Search strings determined by the authors in collaboration with the research librarian were used to retrieve articles from the abovementioned databases. It was decided to make use of free text, as the search would be conducted on multiple databases, of which only MEDLINE and CINAHL utilize controlled vocabulary (MeSH and CINAHL subject headings respectively). Before conducting the search, a concept analysis was done to identify synonyms to be used in the free-text search (see Table 2 for a combination of the search string using Boolean operators). The first author (RJ) also searched the reference lists of retrieved articles. Dissertations and book chapters formed part of the retrieved articles.

Table 2. Search strings used.

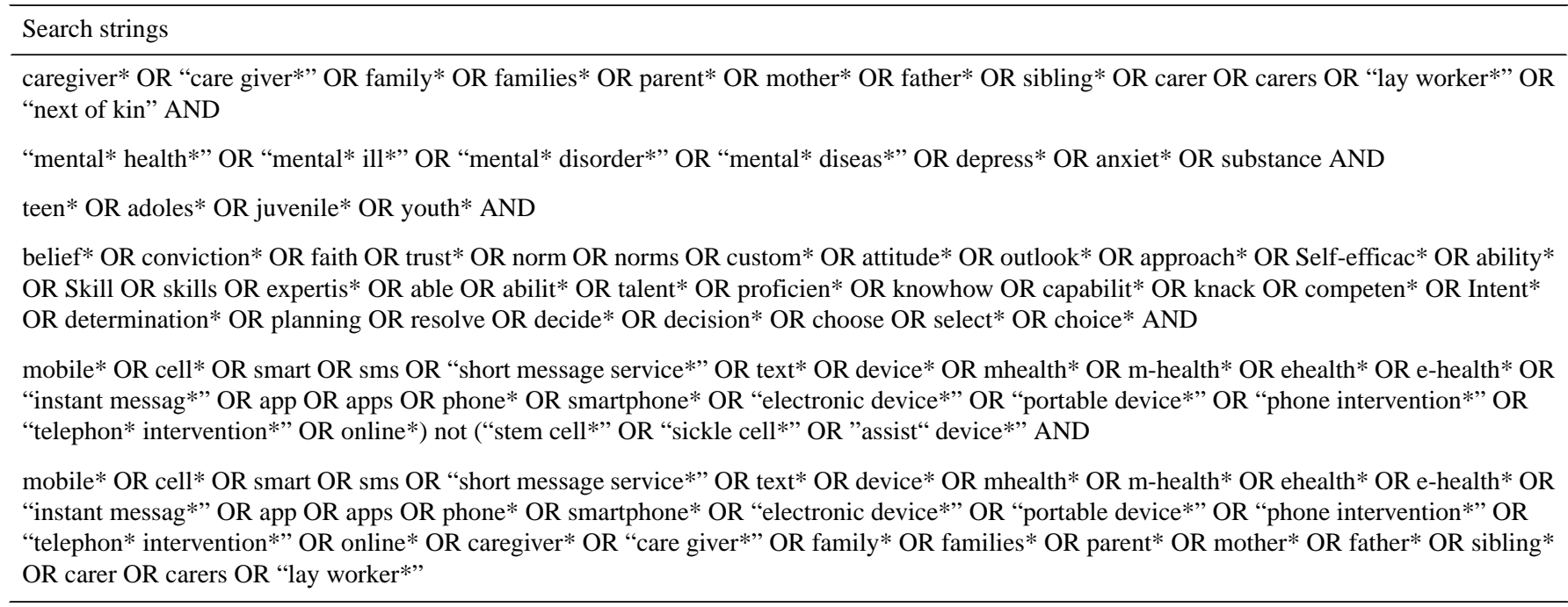




\section{Eligibility Criteria}

Articles were eligible for inclusion if they (1) focused on caregivers such as families, parents, siblings, or relatives of adolescents with mental health issues (concentrating on depression, anxiety, and substance use disorders) as the target population, (2) reported on communication technology usage, and (3) described caregiver determinants according to the IMBP. Articles were excluded if they did not meet the inclusion criteria or (1) if they focused only on adolescents as the target population, (2) if they reported on non-communication technology interventions, and (3) if the focus was on mental health-related therapies or traditional communication interventions.

\section{Selection Procedure}

The first author (RJ) filtered all titles and abstracts obtained from the search against the review question and eligibility criteria. The second author (MR) verified articles for compliance with eligibility criteria. A large number of articles were excluded, and duplicates were removed. Full-texts for the remaining articles were obtained from the librarian. These full-text articles were independently screened for eligibility by both authors, and any discordances were resolved through discussion. Additionally, references of selected articles were screened further for relevant studies.

\section{Quality Appraisal}

The first author (RJ), together with two senior researchers, rigorously evaluated the quality of the selected articles according to the Critical Appraisal Skills Programme [76] and Joanna Briggs Institute assessment tools applicable to each study design [77]. All tools evaluated the appropriateness of methods used, clarity of focus, the recruitment process, the accuracy of measures used, data collection, presentation and analysis, clarity in the statement of the findings, and appropriateness of context. If more than two aspects were not addressed in the articles, it was excluded. This was depicted as either Level $1 *$ (full marks obtained) or Level 1 ( -1 mark) in Table 3. Table 3 includes a hierarchy classification system in terms of research design, according to the American Dietetic Association [78,79]. This critical appraisal of the full-text articles determined the selection and inclusion of articles in this systematic review. 
Table 3. Summary of included articles' study designs.

\begin{tabular}{|c|c|c|c|c|c|}
\hline \multirow[t]{2}{*}{ Extracted data } & \multicolumn{5}{|l|}{ Reference } \\
\hline & Deitz et al [80] & Cardamone-Breen et al [33] & Choi et al [81] & Molleda et al [82] & Estrada et al [83] \\
\hline Design & $\begin{array}{l}\text { Randomized control } \\
\text { trial }\end{array}$ & Randomized control trial & Quasi-experimental & Qualitative, descriptive & $\begin{array}{l}\text { Qualitative inter- } \\
\text { views }\end{array}$ \\
\hline \multicolumn{6}{|l|}{ Grading } \\
\hline Level & 1 & 1 & $1^{*}$ & 1 & 1 \\
\hline Hierarchy & A & A & $\mathrm{C}$ & $\mathrm{D}$ & $\mathrm{D}$ \\
\hline \multicolumn{6}{|l|}{$\begin{array}{l}\text { Communication } \\
\text { technology }\end{array}$} \\
\hline Type & Web-based & Web-based & Web-based & Internet-based, eHealth & $\begin{array}{l}\text { Internet-based, } \\
\text { eHealth, tablets }\end{array}$ \\
\hline Reminders & $\begin{array}{l}\text { Multiple-not speci- } \\
\text { fied }\end{array}$ & - & $\begin{array}{l}\text { Phone calls, text mes- } \\
\text { sages, and emails }\end{array}$ & - & $\begin{array}{l}\text { Phone or text mes- } \\
\text { sages }\end{array}$ \\
\hline $\begin{array}{l}\text { Financial sup- } \\
\text { port }\end{array}$ & $\begin{array}{l}\text { National Institute on } \\
\text { Mental Health }\end{array}$ & $\begin{array}{l}\text { National Health and Medical } \\
\text { Research Council }\end{array}$ & Korean government & - & $\begin{array}{l}\text { Centers for Disease } \\
\text { Control and Preven- } \\
\text { tion (grant) }\end{array}$ \\
\hline Recruitment & - & $\begin{array}{l}\text { Online networks, social me- } \\
\text { dia, computer, online parent } \\
\text { portals, and email communi- } \\
\text { cation }\end{array}$ & Via online communities & Emails & Online \\
\hline Follow-up & & $\begin{array}{l}\text { Phone calls, text messages, } \\
\text { and emails }\end{array}$ & & & \\
\hline \multicolumn{6}{|l|}{ Targeted } \\
\hline Caregivers & Parents, $n=99$ & Parent/caregiver, $\mathrm{n}=349$ & Parents, $n=114$ & Parents, $n=6$ & Parents, $n=29$ \\
\hline $\begin{array}{l}\text { Youth/ adoles- } \\
\text { cents }\end{array}$ & $\begin{array}{l}\text { Mental health prob- } \\
\text { lems or issues }\end{array}$ & $\begin{array}{l}\text { With depression and anxiety } \\
\text { disorders }\end{array}$ & $\begin{array}{l}\text { Mental health problems } \\
\text { or issues (common } \\
\text { mental health problems } \\
\text { (ie, bullying, depres- } \\
\text { sion, internet addiction, } \\
\text { and suicide) }\end{array}$ & $\begin{array}{l}\text { With drug use and risky } \\
\text { sex behavior }\end{array}$ & $\begin{array}{l}\text { With drug use and } \\
\text { sexually risky behav- } \\
\text { ior }\end{array}$ \\
\hline Setting & $\begin{array}{l}\text { Workplace of parents: } \\
\text { ISA Group in Alexan- } \\
\text { dria in the US }\end{array}$ & $\begin{array}{l}\text { Secondary schools in Aus- } \\
\text { tralia }\end{array}$ & $\begin{array}{l}\text { Two elementary } \\
\text { schools and four middle } \\
\text { schools from four cities } \\
\text { in Korea }\end{array}$ & $\begin{array}{l}\text { Pediatric mobile clinic } \\
\text { in Miami-Dade County } \\
\text { and another clinic locat- } \\
\text { ed on the university } \\
\text { medical campus (Uni- } \\
\text { versity of Miami Miller } \\
\text { School of Medicine) }\end{array}$ & $\begin{array}{l}\text { Multiple middle } \\
\text { schools relatively } \\
\text { close to where the } \\
\text { families lived and at } \\
\text { the University of } \\
\text { Miami offices. }\end{array}$ \\
\hline
\end{tabular}

\section{Data Extraction, Analysis, and Synthesis}

The authors extracted specific data from the selected articles in a tabular format to record the study characteristics, types, and delivery method of communication technologies and the strengthening of positive behavior according to IMBP determinants. A meta-analysis was not feasible due to the heterogeneity of the included articles. A thematic data analysis [84-86] took place and both authors discussed the themes to refine the data according to the review question. Subsequently, the data were organized into relevant thematic conclusions addressing the research question based on the PICO elements. After that, the results were synthesized across all articles.

\section{Results}

\section{Search Results and Selection of Articles}

The search identified 1746 electronic records of possible interest. Two additional articles were added, one through contacting an author and another through reference list checking. After electronic and manual removal of duplicates, 1089 records remained. Further screening for eligibility of identified records resulted in the retrieval of 59 full-text articles that were potentially relevant for analysis. The authors then conducted a comprehensive review of these full-text articles and included articles that specifically focused on communication technologies used by caregivers of adolescents with mental health issues. A total of 5 articles met all the eligibility criteria. Figure 1 presents the PRISMA flow diagram of the study, and Table 3 presents a summary of the included articles' study design evaluations. 
Figure 1. PRISMA flow diagram.
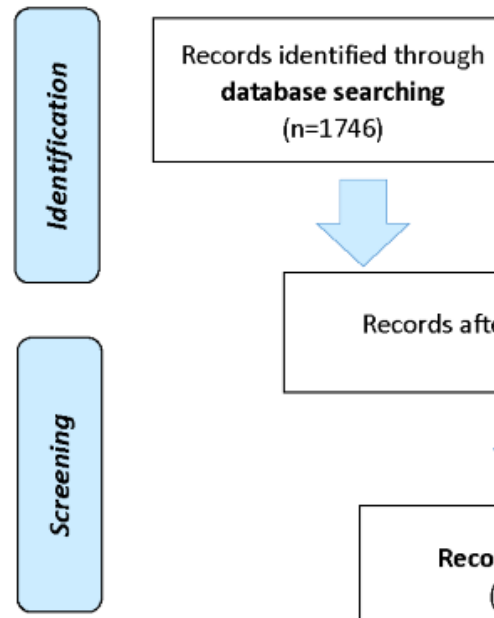
( $n=1089$ )
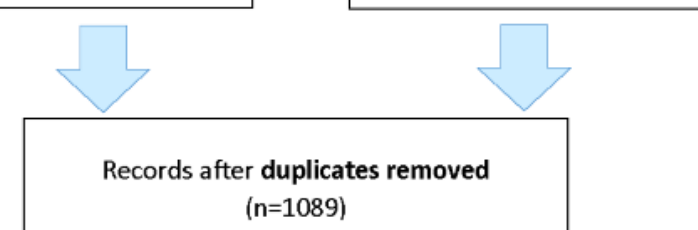

d
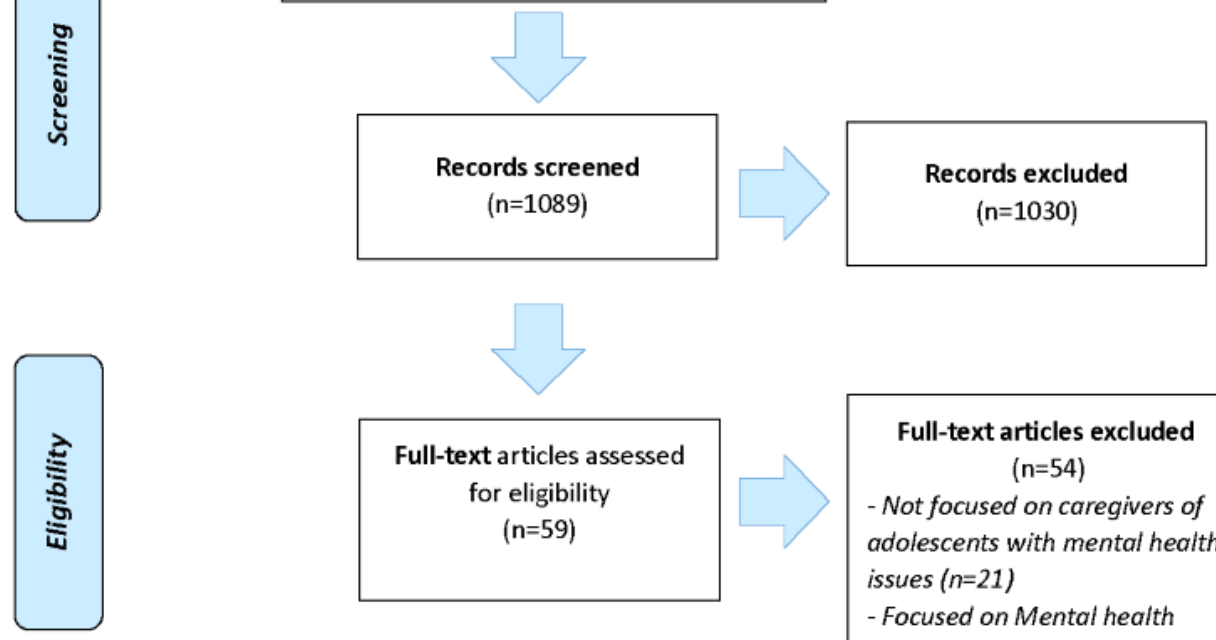

Full-text articles assessed for eligibility $(n=59)$

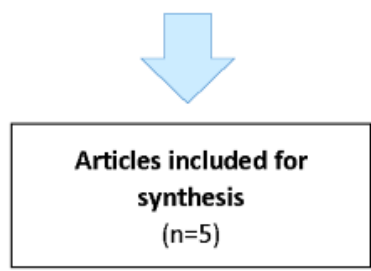

Full-text articles excluded ( $\mathrm{n}=54)$

- Not focused on caregivers of adolescents with mental health issues ( $n=21$ )

- Focused on Mental health related therapies or traditional CTs ( $n=23$ )

- Study protocols $(n=8)$

-Not primary studies $(n=2)$

\section{Characteristics of Included Articles}

The final articles included in this systematic review consisted of multiple designs. There were 2 randomized controlled trials [33,80], 1 quasi-experimental study [81], and 2 qualitative studies [82,83]. In all 5 articles, the caregivers had been exposed to communication technologies in caring for adolescents with mental health issues. Of the 5 studies, 3 studies were performed in the United States [80,82,83], 1 was performed in Australia [33], and 1 was performed in Korea [81]. Articles varied in methodology, intervention, outcomes, measurement scales, and findings. Not all of the articles complied with all of the identified IMBP determinants leading to positive behavior. Table 4 presents a summary of the results reported by the 5 articles.

Results from the 5 articles were synthesized and thematically analyzed to formulate conclusions. The thematic conclusions are discussed according to the types of communication technologies used, caregivers as the target population, and strengthening of positive behavior through IMBP determinants. 
Table 4. Summary of results reported by the 5 articles.

\begin{tabular}{|c|c|}
\hline Reference & Strengthening positive behavior according to determinants within IMBP ${ }^{\mathrm{a}}$ \\
\hline \multirow[t]{5}{*}{ Deitz et al [80] } & Total knowledge score: significantly greater for the experimental group than the control group $(t=-7.96, P<.001)$ \\
\hline & Knowledge of treatment: statistically significant $(t=-2.92, P=.006)$ \\
\hline & $\begin{array}{l}\text { A significant difference was found between experimental and control groups on self-efficacy in handling mental health issues in } \\
\text { their children }(F=12.73, P=.001) \text {. }\end{array}$ \\
\hline & $\begin{array}{l}\text { Significant paired } t \text { test analysis of increases in self-efficacy from pretest to posttest among the individuals receiving the intervention } \\
\text { was found }(t=-3.20, P=.003) \text {. }\end{array}$ \\
\hline & $\begin{array}{l}\text { No significant differences between groups on the measures of family communication, adaptability, cohesion, and attitudes toward } \\
\text { mental health issues were found. }\end{array}$ \\
\hline \multirow[t]{4}{*}{$\begin{array}{l}\text { Cardamone- } \\
\text { Breen et al [33] }\end{array}$} & $\begin{array}{l}\text { Chi-square analyses of the postintervention (1-month) assessment revealed a significant difference in attempts to change parenting } \\
\left(\mathrm{n}=307, \chi_{3}{ }^{2}=19.65, P<.001\right) \text {, with significantly more intervention group parents reporting making some changes to their parenting. }\end{array}$ \\
\hline & $\begin{array}{l}\text { The majority of parents }(93.6 \%) \text { reported they were somewhat or very satisfied with the feedback received, and } 95.1 \% \text { reported } \\
\text { the feedback as either somewhat, very, or extremely useful. }\end{array}$ \\
\hline & Most parents $(90.2 \%)$ reported they were somewhat or very likely to change their parenting based on the feedback provided. \\
\hline & Conclusion: accessible, low-cost preventive approach \\
\hline \multirow[t]{4}{*}{ Choi et al [81] } & $\begin{array}{l}\text { Participants in the intervention, compared to those in the control group, demonstrated preliminary evidence of improved parental } \\
\text { knowledge. }\end{array}$ \\
\hline & The effect size of parental knowledge was large ( $\mathrm{d}=0.60 ; 95 \%$ CI $0.21-0.99)$. \\
\hline & $\begin{array}{l}\text { Parents in the intervention group showed increased parental self-efficacy, parent-child communication, and satisfaction with parent- } \\
\text { child relationships, and decreased parent-child conflict. }\end{array}$ \\
\hline & Parents reported accessibility and convenience to complete the intervention. \\
\hline \multirow[t]{3}{*}{ Molleda et al [82] } & Effective parent-adolescent communication skills. \\
\hline & Parents' positive experience with flexibility, accessibility, and convenience in delivery of eHealth. \\
\hline & Parents also reported the ability to apply the lessons learned from eHealth Familias Unidas to their daily lives. \\
\hline \multirow[t]{4}{*}{ Estrada et al [83] } & It was feasible to recruit, engage, and retain Hispanic families into an eHealth intervention and deliver it electronically. \\
\hline & Positive feedback was provided by the parents regarding eHealth. \\
\hline & $\begin{array}{l}\text { Parents stated there were multiple lessons learned from engaging in eHealth Familias Unidas: effective parent-adolescent commu- } \\
\text { nication and active parental attention and involvement in an adolescent's life. }\end{array}$ \\
\hline & $\begin{array}{l}\text { Culturally appropriate online content allowed parents to access sessions at their convenience and minimized costs for researchers } \\
\text { and participants alike }\end{array}$ \\
\hline
\end{tabular}

${ }^{\mathrm{a}}$ IMBP: Integrated Model of Behavior Prediction.

\section{Types of Communication Technologies Used}

All the studies implemented web-based interventions [33,80-83]. Content employed via the communication technologies and delivery thereof varied considerably. The web-based program by Deitz et al [80] consisted of 4 multimedia modules that provided information regarding symptoms and treatment options for depression and anxiety, building parental skills, and additional resources with information about mental health issues. Parental skills included communication, relationships, and healthy lifestyles. Estrada et al [83] and Molleda et al [82] adapted an evidence-based intervention, Familias Unidas, into a web-based intervention consisting of 8 e-parent group sessions of video recordings and 4 online family sessions (parent-adolescent) with a facilitator. Choi et al [81] reported on a 4-week web-based intervention (Stepping-stone) containing educational sessions, media files, verbal feedback, weekly assignments, and practice sessions regarding bullying, depression, suicide, and communication skills. Cardamone-Breen et al [33] adapted a single-session web-based component of the Partners in Parenting intervention. This intervention provided personalized feedback and psychoeducation concerning guidelines on adolescent depression and anxiety after the parents completed an online survey to assess parenting practices.

\section{Target Population}

The study populations in the included articles predominantly comprised caregivers as parents or family members. Deitz et al [80] used parents or caregivers of youth between the ages 5 and 21, while Molleda et al [82] included clinic personnel, facilitators (ie, physicians, nurse practitioners, administrators, and mental health workers), and parents or primary caregivers of Hispanic adolescents (age range: 12 to 16 years) [82]. Estrada et al [83] also included Hispanic families with parents and adolescents between the ages of 12 and 16 [83]. The study by Choi et al [81] encompassed parents who had at least one child aged 11 to 16 years. Cardamone-Breen et al [33] used a community sample of parents, together with adolescents aged 12 to 15 years old. The most common problems among adolescents were mental health or behavioral issues [80,81], depression and anxiety disorders [33,81], bullying [81], suicide [81], and substance use [82,83]. The majority of participants in the studies were female, recruited from various urban settings, and educated. 


\section{IMBP and Other Determinants}

Outcomes focusing on the IMBP determinants in the current review were about self-efficacy and skills such as parent-child communication: 2 studies [80,81] measured the effect of the intervention on caregiver self-efficacy that improved after the intervention; 3 studies [81-83] also demonstrated the effectiveness of communication skills between caregiver and adolescent, and 1 randomized controlled trial [80] measured no significant differences between study groups in family communication skills. Of the 5 studies, Cardamone-Breen et al's study [33] showed promising changes in parenting skills and behavior, and another study [80], a randomized control trial, reported outcomes regarding parental attitudes demonstrating no significant differences between the two study groups.

Another observation was that effective parental skills resulted in satisfactory parent-child relationships as well as a decline in parent-child conflict [81]. Caregivers similarly appreciated the feedback they received regarding their parental skills after using the intervention [33] and lessons learned to implement in their daily lives $[82,83]$.

We identified 2 studies [80,81] that measured the effect of communication technologies use on caregivers' knowledge showing an improvement. Additionally, Estrada et al [83] found that parents were more involved and attentive in the life of adolescents after engaging with the eHealth intervention. In turn, participants in Estrada et al's study [83] gave positive feedback regarding the use of the eHealth intervention while Molleda et al [82] found that parents experienced the eHealth delivery as positive.

\section{Discussion}

\section{Principal Findings}

The review results show the potential value of communication technologies to strengthen caregivers' behavior when caring for an adolescent with mental health issues. Overall, the results yielded evidence of the usefulness of communication technologies by caregivers. Moreover, the results contributed to the limited literature on communication technology interventions for caregivers caring for the adolescent with mental health issues.

As shown by this study, the results were mostly positive, which may raise questions about selection bias. Aligned to the review question, we were interested in determinants showing improved outcomes among caregivers' when using communication technologies. It becomes particularly imperative to recognize users' preferences and acceptance of communication technologies in a health care setting. Identifying appropriate communication technologies to inform and support caregivers may be a challenge, but it is essential to understand their adoption thereof $[87,88]$. Information dissemination delivered through communication technologies is gradually replacing traditional approaches [89], but the implementation in health care [90] and among caregivers [14,91] is still lacking.

Communication technologies can distribute an unprecedented amount of information through technology such as electronic devices, system software, and information networks such as the internet, which provides access to resources [92,93]. Moreover, Schneider's [94] systematic review reported that utilizing communication technologies to gather and stream information received the highest proportion of use. Multimedia approaches including internet and web-based programs are a means for providing informational support to caregivers; they also found that effective parent education through communication technologies can augment the mental well-being of children [95]. Our results are consistent with earlier reports in this field that suggest that web-based interventions are effective for caregivers managing mental health issues in adolescents $[91,96,97]$.

A prevailing expectation of communication technologies is that it might improve knowledge acquisition regarding illnesses. However, applicable information should be according to the caregivers' specific needs [98]. Statistically significant differences were found related to parental outcomes of knowledge, attitudes, and skills in efficient web-based interventions [99]. Exploiting the internet for knowledge about chronic diseases, as noted by Mahmud et al [53], can assist individuals and communities in health promotion. In contrast, low-income parents were not confident in using the internet and could not distinguish between good- or bad-quality information [100]. Sweeney et al [59] concluded that parents of youth with mental health problems demonstrated poor knowledge regarding computer-based therapies but were positive about using it.

Communication technologies are now mature enough to enable learning and knowledge exchange among caregivers in health care [101]. This functionality is attributable to the fact that communication technologies are associated with boosting the health care landscape through information exchange and transformation among large populations [102]. Our review indicated some evidence that computer-based interventions among large groups of parents are less expensive. The financial implication is particularly relevant in the current global socioeconomic climate, especially in low-resource settings that should keep cost-effectiveness of communication technologies in mind [103] when serving vulnerable populations such as caregivers in deploying health care [104]. According to Sprague et al [105], the world still experiences barriers to internet adoption despite high technology penetration because of disproportionately rural populations, low-income, illiteracy, elderly users, and female users. Therefore, it is vital to explore the best evidence available related to communication technologies barriers such as delivery methods, cost-effectiveness, caregiver characteristics, and outcomes, which will predict adoption thereof.

None of the included studies measured text messaging, phone calls, mobile apps, or social networking as a favored network delivery; however, included studies mentioned the use of communication technologies to recruit participants and send reminders. Domek et al [106] and Anderson-Lewis et al [107] suggest that text message interventions may be useful in rural families and have the potential to disseminate public health information. Mobile apps show some promise in serving families of youth with mental health issues in resource-constraint settings [108]. Breitenstein et al [109] also determined that digital delivery, such as mobile apps, might theoretically be 
cost-effective, sustainable, and reach large numbers for parent training. Furthermore, some studies $[110,111]$ have shown that social media effectively supports and informs caregivers through shared participation. Catalano et al [112] identified that parental social support and interacting improved caregiver well-being.

Collective participation is valuable, but researchers should be mindful of caregivers' individuality when exploring the usage of communication technologies. It is important to conceptualize the characteristics of caregivers in the context of communication technologies acceptance [113-115]. Caregivers of adolescents are typically a parent or family member who assumes a central role in caregiving. Transition into the caregiver role can be different for each caregiver. Recognizing the individual needs of each caregiver is crucial when investigating the usability of communication technology interventions $[9,116]$, especially in caregivers of children or adolescents with mental health issues $[67,117,118]$.

Caregivers' adoption of tailored web-based interventions focusing on their needs may improve their resourcefulness and mobilize effective caregiving [119,120]. Tailored communication technologies was highlighted in this review, indicating contextual relevance related to the usage of communication technologies. Besides, this review also highlighted common elements depicting their approval of utilizing communication technologies, such as the accessibility, cost-effectiveness, convenience, and flexibility thereof. Generally, study participants gave positive feedback related to communication technologies use. Modifying communication technology interventions to match caregivers' preferences might lead to favorable changes in parenting practices and satisfaction in intervention utility [121]. Overall, the findings demonstrated the acceptability of communication technologies by caregivers, and the use of communication technologies was associated with improved caregiver and mental health outcomes among adolescents.

Some studies in this review identified diverse interventions that facilitated the strengthening of caregivers' behavior, such as improved self-efficacy, enhanced knowledge, and better parent-child communication skills and practices. These findings complement those of other studies in that online tools have proved to be successful in improving caregivers' knowledge, skills, coping [122,123], and self-efficacy [120,124]. Nieuwboer et al [99] summarized that the internet supplies information, support and advice to parents with different needs that encourage changes in their parental abilities. Furthermore, technology provides access to others for building support and knowledge through positive engagement [125]. Reportedly, the potential impact of communication technologies on caregivers' well-being is ubiquitous and may guide their behavior toward the care recipient [126].

Caregivers who feel that they can perform behavior effectively will continue to repeat that specific behavior. This performance is based on knowledge, skills, and self-efficacy. A repetition of the behavior will occur if it is associated with a positive feeling and a sense of confidence; the accomplishment of the behavior, reflects self-efficacy and competency in performing the task $[127,128]$. People hold specific beliefs about behavior and intentionally perform according to that belief. From the IMBP, people who have the necessary skills will perform more satisfactorily, which will lead to favorable outcomes [129]. Hall and Bierman [130] reported improvement in parental knowledge and attitude through technology-based interventions. Of course, targeted interventions strengthening parental knowledge, self-efficacy, and skills may lead to improved child mental health outcomes [100] and positive parental outcomes [9].

Thus, it is legitimate to say that a communication technologies-based intervention has great potential to be used by caregivers to reinforce positive behavior when caring for an adolescent with mental health issues. Communication technologies also represent possibilities to provide support to caregivers by addressing their individual needs which could be highly convoluted. This review shows a need for further research in the area of supporting caregivers of adolescents with mental health issues.

\section{Strengths}

The authors conducted a comprehensive review following a stepwise methodological process for a systematic review. We included multiple study designs to understand how communication technologies may strengthen caregivers' behavior and improve caregiver outcomes. We used standardized checklists to appraise selected articles critically. The results provided knowledge related to the use of communication technologies among caregivers of adolescents with mental health issues.

\section{Limitations}

We might have missed potentially relevant articles, although explicit inclusion and exclusion criteria were set up. The first author initially screened titles and abstracts independently for applicability while some were verified by the second author for quality control purposes. This review was limited to articles describing caregiver outcomes according to the IMBP determinants, and this restriction may have eliminated meaningful information from other communication technology advantages.

\section{Conclusions}

The review results indicate that using communication technology is useful to strengthen caregivers' behavior by providing information and resources. Additionally, a better understanding of caregivers' attitudes and environmental constraints toward communication technologies may inform optimal usefulness thereof. Evidence for caregivers of adolescents with mental health issues using communication technologies is not readily available in the literature. There was limited empirical research outlining the methods of communication delivery, and it is worth exploring this in future research. Besides, future research should focus on the development of more innovative communication technology interventions for caregivers in different contexts and scaling up of efforts to implement them for improved mental health care among adolescents. 


\section{Acknowledgments}

This study was made possible by funding received from the Free State Department of Health (DOH 81/16/17) and financial support from the University of the Free State, Bloemfontein, South Africa.

The authors would also like to thank Mrs. Annamarie du Preez (senior librarian) for assisting with the search strategy as well as the two senior researchers, Dr Deidre van Jaarsveldt and Dr Cynthia Spies for the quality appraisal process.

\section{Authors' Contributions}

RJ and MR conceptualized and designed the study. RJ and MR developed search strategies. RJ and MR conducted data extraction, analysis, and synthesis. MR contributed to the revision and approval of the manuscript.

\section{Conflicts of Interest}

None declared.

\section{References}

1. Delbanco T, Berwick D, Boufford J, Edgman-Levitan P, Ollenschläger G, Plamping D. Healthcare in a land called peoplepower: Nothing about me without me. Heal Expect 2001;4:144-150. [doi: 10.1046/j.1369-6513.2001.00145.x]

2. Margolis KL, Fosco GM, Stormshak EA. Circle of Care: Extending Beyond Primary Caregivers to Examine Collaborative Caretaking in Adolescent Development. J Fam Issues 2016 Jun;37(9):1179-1202 [FREE Full text] [doi: 10.1177/0192513X14536565] [Medline: 27453615]

3. Adelman RD, Tmanova LL, Delgado D, Dion S, Lachs MS. Caregiver Burden. JAMA 2014 Mar 12;311(10):1052. [doi: 10.1001/jama.2014.304]

4. Dookie S, Singh S. Primary health services at district level in South Africa: a critique of the primary health care approach. BMC Fam Pract 2012 Jul 2;13(1). [doi: 10.1186/1471-2296-13-67]

5. McInnis MG, Merajver SD. Global mental health: Global strengths and strategies. Asian Journal of Psychiatry 2011 Sep;4(3):165-171. [doi: 10.1016/j.ajp.2011.06.002]

6. Healy EA, Kaiser BN, Puffer ES. Family-based youth mental health interventions delivered by nonspecialist providers in low- and middle-income countries: A systematic review. Families, Systems, \& Health 2018 Jun;36(2):182-197. [doi: 10.1037/fsh0000334]

7. Angothu H, Chaturvedi S. Civic and legal advances in the rights of caregivers for persons with severe mental illness related disability. Indian J Soc Psychiatry 2016;32(1):28. [doi: 10.4103/0971-9962.176764]

8. Musyimi CW, Mutiso VN, Ndetei DM, Unanue I, Desai D, Patel SG, et al. Mental health treatment in Kenya: task-sharing challenges and opportunities among informal health providers. Int J Ment Health Syst 2017 Aug 1;11(1). [doi: 10.1186/s13033-017-0152-4]

9. Talley R, Fricchione G, Druss B. Introduction: Caregiving to promote mental health and prevent mental illness. In: Talley R, editor. The challenges of mental health caregiving. Research - Practice - Policy. New York: Springer; 2014:1-14.

10. Collins LG, Swartz K. Caregiver care. Am Fam Physician 2011 Jun 01;83(11):1309-1317 [FREE Full text] [Medline: 21661713]

11. Penning MJ, Wu Z. Caregiver Stress and Mental Health: Impact of Caregiving Relationship and Gender. GERONT 2015 Apr 17;56(6):1102-1113. [doi: 10.1093/geront/gnv038]

12. Joslin D. Introduction. In: Joslin D. editor. Invisible care givers: Older Adults Raising Children in the Wake of HIV/AIDS. New York: Columbia University Press; 2002:1-26.

13. Mayberry LS, Heflinger CA. How Caregivers Make Meaning of Child Mental Health Problems: Toward Understanding Caregiver Strain and Help Seeking. Fam Soc 2013 May;94(2):105-113 [FREE Full text] [doi: 10.1606/1044-3894.4286] [Medline: 27293367]

14. Bergström AL, Hanson E. An integrative review of information and communication technology based support interventions for carers of home dwelling older people. TAD 2018 Feb 05;29(1-2):1-14. [doi: 10.3233/tad-160158]

15. Hughes S, Shuman S, Wiener J, Gould E. Background paper. In: Research Summit on Dementia Care. Washington: RTI International; Mar 2017:12.

16. Chang S, Zhang Y, Jeyagurunathan A, Lau YW, Sagayadevan V, Chong SA, et al. Providing care to relatives with mental illness: reactions and distress among primary informal caregivers. BMC Psychiatry 2016 Mar 25;16:80 [FREE Full text] [doi: 10.1186/s12888-016-0786-9] [Medline: 27016185]

17. Roth D, Fredman L, Haley W. Informal caregiving and its impact on health: A reappraisal from population-based studies. Gerontologist 2015;55(2):309-319. [doi: 10.1093/geront/gnu177]

18. Jackson D, Roberts G, Wu ML, Ford R, Doyle C. A systematic review of the effect of telephone, internet or combined support for carers of people living with Alzheimer's, vascular or mixed dementia in the community. Archives of Gerontology and Geriatrics 2016 Sep;66:218-236. [doi: 10.1016/j.archger.2016.06.013] 
19. Waller A, Dilworth S, Mansfield E, Sanson-Fisher R. Computer and telephone delivered interventions to support caregivers of people with dementia: a systematic review of research output and quality. BMC Geriatr 2017 Nov 16;17(1). [doi: $\underline{10.1186 / \mathrm{s} 12877-017-0654-6]}$

20. Lambert SD, Girgis A. Unmet Supportive Care Needs Among Informal Caregivers of Patients with Cancer: Opportunities and Challenges in Informing the Development of Interventions. Asia Pac J Oncol Nurs 2017;4(2):136-139 [FREE Full text] [doi: 10.4103/2347-5625.204485] [Medline: 28503646]

21. Luker K, Cooke M, Dunn L, Lloyd-Williams M, Pilling M, Todd C. Development and evaluation of an intervention to support family caregivers of people with cancer to provide home-based care at the end of life: a feasibility study. Eur J Oncol Nurs 2015 Apr;19(2):154-161. [doi: 10.1016/j.ejon.2014.09.006] [Medline: 25667125]

22. Mbuagbaw L, Mursleen S, Lytvyn L, Smieja M, Dolovich L, Thabane L. Mobile phone text messaging interventions for HIV and other chronic diseases: an overview of systematic reviews and framework for evidence transfer. BMC Health Serv Res 2015 Jan 22;15(1). [doi: 10.1186/s12913-014-0654-6]

23. Winskell K, Miller KS, Allen KA, Obong'o CO. Guiding and supporting adolescents living with HIV in sub-Saharan Africa: The development of a curriculum for family and community members. Children and Youth Services Review 2016 Feb;61:253-260. [doi: 10.1016/j.childyouth.2015.12.017]

24. Badawy SM, Barrera L, Sinno MG, Kaviany S, O’Dwyer LC, Kuhns LM. Text Messaging and Mobile Phone Apps as Interventions to Improve Adherence in Adolescents With Chronic Health Conditions: A Systematic Review. JMIR Mhealth Uhealth 2017 May 15;5(5):e66. [doi: 10.2196/mhealth.7798]

25. Kim J, Lee S. Communication and cybercoping: coping with chronic illness through communicative action in online support networks. J Health Commun 2014 Feb;19(7):775-794. [doi: 10.1080/10810730.2013.864724] [Medline: 24559492]

26. Anstey Watkins J, Goudge J, Gómez-Olivé FX, Huxley C, Dodd K, Griffiths F. mHealth text and voice communication for monitoring people with chronic diseases in low-resource settings: a realist review. BMJ Glob Health 2018 Mar;3(2):e000543 [FREE Full text] [doi: 10.1136/bmjgh-2017-000543] [Medline: 29527356]

27. Lee SH, Nurmatov UB, Nwaru BI, Mukherjee M, Grant L, Pagliari C. Effectiveness of mHealth interventions for maternal, newborn and child health in low- and middle-income countries: Systematic review and meta-analysis. J Glob Health 2016 Jun;6(1):010401 [FREE Full text] [doi: 10.7189/jogh.06.010401] [Medline: 26649177]

28. Chen H, Chai Y, Dong L, Niu W, Zhang P. Effectiveness and Appropriateness of mHealth Interventions for Maternal and Child Health: Systematic Review. JMIR Mhealth Uhealth 2018 Jan 09;6(1):e7. [doi: 10.2196/mhealth.8998]

29. Phillips JH, Wigger C, Beissbarth J, McCallum GB, Leach A, Morris PS. Can mobile phone multimedia messages and text messages improve clinic attendance for Aboriginal children with chronic otitis media? A randomised controlled trial. $\mathrm{J}$ Paediatr Child Health 2014 Feb 25;50(5):362-367. [doi: 10.1111/jpc.12496]

30. Smith J, Cheater F, Bekker H. Parents' experiences of living with a child with a long-term condition: a rapid structured review of the literature. Health Expect 2013 Jan 14;18(4):452-474. [doi: 10.1111/hex.12040]

31. Rodríguez-Meirinhos A, Antolín-Suárez L, Oliva A. Support Needs of Families of Adolescents With Mental Illness: A Systematic Mixed Studies Review. Arch Psychiatr Nurs 2018 Dec;32(1):152-163. [doi: 10.1016/j.apnu.2017.09.004] [Medline: 29413065]

32. O'Loughlin K, Althoff RR, Hudziak JJ. Health Promotion and Prevention in Child and Adolescent Mental Health. In: Rey JM, editor. IACAPAP e-Textbook of Child and Adolescent Mental Health. Geneva: International Association for Child and Adolescent Psychiatry and Allied Professions; 2017:1-25.

33. Cardamone-Breen MC, Jorm AF, Lawrence KA, Rapee RM, Mackinnon AJ, Yap MBH. A Single-Session, Web-Based Parenting Intervention to Prevent Adolescent Depression and Anxiety Disorders: Randomized Controlled Trial. J Med Internet Res 2018 Apr 26;20(4):e148. [doi: 10.2196/jmir.9499]

34. Lund C, Brooke-Sumner C, Baingana F, Baron EC, Breuer E, Chandra P, et al. Social determinants of mental disorders and the Sustainable Development Goals: a systematic review of reviews. The Lancet Psychiatry 2018 Apr;5(4):357-369. [doi: 10.1016/s2215-0366(18)30060-9]

35. Patel V, Chisholm D, Parikh R, Charlson FJ, Degenhardt L, Dua T, et al. Addressing the burden of mental, neurological, and substance use disorders: key messages from Disease Control Priorities, 3rd edition. The Lancet 2016 Apr;387(10028):1672-1685. [doi: 10.1016/s0140-6736(15)00390-6]

36. Pedersen GA, Smallegange E, Coetzee A, Hartog K, Turner J, Jordans MJD, et al. A Systematic Review of the Evidence for Family and Parenting Interventions in Low- and Middle-Income Countries: Child and Youth Mental Health Outcomes. J Child Fam Stud 2019 Apr 29;28(8):2036-2055. [doi: 10.1007/s10826-019-01399-4]

37. Paruk S, Karim E. Update on adolescent mental health. S Afr Med J 2016 May 14;106(6):548. [doi: 10.7196/samj.2016.v106i6.10943]

38. Patel V, Saxena S, Lund C, Thornicroft G, Baingana F, Bolton P, et al. The Lancet Commission on global mental health and sustainable development. The Lancet 2018 Oct;392(10157):1553-1598. [doi: 10.1016/s0140-6736(18)31612-x]

39. Erskine HE, Baxter AJ, Patton G, Moffitt TE, Patel V, Whiteford HA, et al. The global coverage of prevalence data for mental disorders in children and adolescents. Epidemiol Psychiatr Sci 2016 Jan 20;26(4):395-402. [doi:

$10.1017 / \mathrm{s} 2045796015001158]$ 
40. Armoiry X, Sturt J, Phelps EE, Walker C, Court R, Taggart F, et al. Digital Clinical Communication for Families and Caregivers of Children or Young People With Short- or Long-Term Conditions: Rapid Review. J Med Internet Res 2018 Jan 05;20(1):e5. [doi: 10.2196/jmir.7999]

41. Kuhn ES, Laird RD. Family support programs and adolescent mental health: review of evidence. Adolesc Health Med Ther 2014 Jul;5:127-142 [FREE Full text] [doi: 10.2147/AHMT.S48057] [Medline: 25177156]

42. Maar MA, Yeates K, Perkins N, Boesch L, Hua-Stewart D, Liu P, et al. A Framework for the Study of Complex mHealth Interventions in Diverse Cultural Settings. JMIR Mhealth Uhealth 2017 Apr 20;5(4):e47. [doi: 10.2196/mhealth.7044]

43. Sheets DJ, Black K, Kaye LW. Who cares for caregivers? Evidence-based approaches to family support. J Gerontol Soc Work 2014 Aug;57(6-7):525-530. [doi: 10.1080/01634372.2014.920606] [Medline: 25105462]

44. Metzler CW, Sanders MR, Rusby JC, Crowley RN. Using consumer preference information to increase the reach and impact of media-based parenting interventions in a public health approach to parenting support. Behav Ther 2012 Jun;43(2):257-270 [FREE Full text] [doi: 10.1016/j.beth.2011.05.004] [Medline: 22440064]

45. Issel L. Health Program Planning and Evaluation. A practical, systematic approach for community health. Third edit. Burlington: Jones \& Bartlett Learning books; 2014:1-613.

46. Yesufu-Udechuku A, Harrison B, Mayo-Wilson E, Young N, Woodhams P, Shiers D, et al. Interventions to improve the experience of caring for people with severe mental illness: systematic review and meta-analysis. Br J Psychiatry 2015 Apr;206(4):268-274. [doi: 10.1192/bjp.bp.114.147561] [Medline: 25833867]

47. Davis TL, DiClemente R, Prietula M. Taking mHealth Forward: Examining the Core Characteristics. JMIR Mhealth Uhealth 2016 Aug 10;4(3):e97 [FREE Full text] [doi: 10.2196/mhealth.5659] [Medline: 27511612]

48. Delponte L, Grigolini M, Moroni A, Vignetti S, Claps M. ICT in the Developing World. Scientific Foresight Unit. Brussels: European Parliamentary Research Service; 2015 Dec. URL: https://www.europarl.europa.eu/thinktank/en/document. html?reference=EPRS_STU(2015)563482 [accessed 2020-08-17]

49. Orlowski SK, Lawn S, Venning A, Winsall M, Jones GM, Wyld K, et al. Participatory Research as One Piece of the Puzzle: A Systematic Review of Consumer Involvement in Design of Technology-Based Youth Mental Health and Well-Being Interventions. JMIR Human Factors 2015 Jul 09;2(2):e12. [doi: 10.2196/humanfactors.4361]

50. Hemmat M, Ayatollahi H, Maleki M, Saghafi F. Future Research in Health Information Technology: A Review. Perspect Heal Inf Manag 2017 Jan 01;14(Winter):A. [Medline: 28566991]

51. Baker S. Broadening the reach of evidence-based parenting interventions: Evaluation of a brief online version of the Triple P - Positive Parenting Program. Doctoral thesis. Queensland: University of Queensland; 2016. URL: https://espace. library.uq.edu.au/view/UQ:466891 [accessed 2020-08-18]

52. Hou S, Charlery SR, Roberson K. Systematic literature review of Internet interventions across health behaviors. Health Psychol Behav Med 2014 Jan 1;2(1):455-481 [FREE Full text] [doi: 10.1080/21642850.2014.895368] [Medline: 25750795]

53. Mahmud AJ, Olander E, Eriksén S, Haglund BJ. Health communication in primary health care -a case study of ICT development for health promotion. BMC Med Inform Decis Mak 2013 Jan 30;13:17 [FREE Full text] [doi: 10.1186/1472-6947-13-17] [Medline: 23363566]

54. Vergunst R. From global-to-local: rural mental health in South Africa. Glob Health Action 2018 Jan;11(1):1413916. [doi: 10.1080/16549716.2017.1413916] [Medline: 29320947]

55. MacDonell KW, Prinz RJ. A Review of Technology-Based Youth and Family-Focused Interventions. Clin Child Fam Psychol Rev 2016 Oct 27;20(2):185-200. [doi: 10.1007/s10567-016-0218-x]

56. Nagata JM, Ferguson BJ, Ross DA. Research Priorities for Eight Areas of Adolescent Health in Low- and Middle-Income Countries. J Adolesc Health 2016 Dec;59(1):50-60 [FREE Full text] [doi: 10.1016/j.jadohealth.2016.03.016] [Medline: 27235375]

57. Breitenstein SM, Shane J, Julion W, Gross D. Developing the CPP: Adapting an Evidence-Based Parent Training Program for Digital Delivery in Primary Care Settings. Worldviews on Evidence-Based Nursing 2015 Jan 14;12(1):31-40. [doi: 10.1111/wvn.12074]

58. DeHoff BA, Staten LK, Rodgers RC, Denne SC. The Role of Online Social Support in Supporting and Educating Parents of Young Children With Special Health Care Needs in the United States: A Scoping Review. J Med Internet Res 2016 Dec 22;18(12):e333. [doi: 10.2196/jmir.6722]

59. Sweeney GM, Donovan CL, March S, Laurenson SD. Logging into therapy: Parent attitudes and intentions to use computer-based therapies for youth mental health. Internet Interventions 2015 Nov;2(4):437-445. [doi: 10.1016/j.invent.2015.11.001]

60. Schwinn TM, Schinke S, Fang L, Kandasamy S. A web-based, health promotion program for adolescent girls and their mothers who reside in public housing. Addict Behav 2014 Apr;39(4):757-760 [FREE Full text] [doi: 10.1016/j.addbeh.2013.11.029] [Medline: 24447886]

61. Russell BS, Maksut JL, Lincoln CR, Leland AJ. Computer-mediated parenting education: Digital family service provision. Children and Youth Services Review 2016 Mar;62:1-8. [doi: 10.1016/j.childyouth.2016.01.012]

62. Torous J, Friedman R, Keshavan M. Smartphone Ownership and Interest in Mobile Applications to Monitor Symptoms of Mental Health Conditions. JMIR mHealth uHealth 2014 Jan 21;2(1):e2. [doi: 10.2196/mhealth.2994] 
63. Casale M, Cluver L, Crankshaw T, Kuo C, Lachman J, Wild L. Direct and Indirect Effects of Caregiver Social Support on Adolescent Psychological Outcomes in Two South African AIDS-Affected Communities. Am J Community Psychol 2015 Jan 27;55:336-346. [doi: 10.1007/s10464-015-9705-3]

64. Robila M. Families, Mental Health and Well Being: Pursuing Sustainable Development Goal 3. In: Family policies and the 2030 Sustainable Development Agenda. New York: United Nations; 2016 May Presented at: Family policies and the 2030 Sustainable Development Agenda; 12-13 May 2016; New York p. 1-15 URL: https://www.un.org/development/desa/ family/meetings-events/family-policies-and-the-2030-sustainable-development-agenda.html

65. Carretero S, Stewart J, Centeno C. Information and communication technologies for informal carers and paid assistants: benefits from micro-, meso-, and macro-levels. Eur J Ageing 2015 Jan 24;12(2):163-173. [doi: 10.1007/s10433-015-0333-4]

66. Jang J, Hessel H, Dworkin J. Parent ICT use, social capital, and parenting efficacy. Computers in Human Behavior 2017 Jun;71:395-401. [doi: 10.1016/j.chb.2017.02.025]

67. Isa SNI, Ishak I, Ab Rahman A, Mohd Saat NZ, Che Din N, Lubis SH, et al. Health and quality of life among the caregivers of children with disabilities: A review of literature. Asian J Psychiatr 2016 Oct;23:71-77. [doi: 10.1016/j.ajp.2016.07.007] [Medline: 27969083]

68. Fishbein M, Ajzen I. Predicting and changing behavior. The Reasoned Action Approach. New York: Psychology Press. Taylor \& Francis Group; 2010:1-539.

69. Dai M, Wombacher K, Matig JJ, Harrington NG. Using the Integrative Model of Behavioral Prediction to Understand College Students' Hookup Sex Beliefs, Intentions, and Behaviors. Health Commun 2018 Sep;33(9):1078-1087. [doi: 10.1080/10410236.2017.1331306] [Medline: 28622006]

70. Montano DE, Kasprzyk D. Theory of reasoned action, theory of planned behavior, and the integrated behavioral model. In: Glanz K, Rimer BK, Viswanath K, editors. Health behavior and Health education. Theory, Research and Practice. 4th editio. San Francisco: John Wiley \& Sons, Inc; 2008:67-96.

71. Rey N. Adhering to healthy behavior. In: Brannon L, Feist J, Updegraff JA, editors. Health Psychology: An Introduction to Behavior and Health. Belmont: Wadsworth: Cengage Learning; 2013:58-86.

72. Fishbein M, Yzer MC. Using Theory to Design Effective Health Behavior Interventions. Commun Theory 2003 May;13(2):164-183. [doi: 10.1111/j.1468-2885.2003.tb00287.x]

73. Gough D, Oliver S, Thomas J. Introducing systematic reviews. In: Gough D, Oliver S, Thomas J, editors. An introduction to Systematic Reviews. London: SAGE; 2012:1-16.

74. Hong QN, Pluye P. A Conceptual Framework for Critical Appraisal in Systematic Mixed Studies Reviews. Journal of Mixed Methods Research 2018 Apr 21;13(4):446-460. [doi: 10.1177/1558689818770058]

75. Petticrew M, Roberts H. Why do we need systematic reviews? In: Systematic reviews in the social sciences. Malden: Blackwell Publishing Ltd; 2006:1-26.

76. CASP. Critical Appraisal Skills Programme (CASP). https://casp-uk.net/casp-tools-checklists/. Oxford: CASP; 2018. URL: https://casp-uk.net/casp-tools-checklists/ [accessed 2018-10-01]

77. Godfrey C, Harrison M. Systematic review resource package. The Joanna Briggs Institute method for systematic review research quick reference guide. 2015. URL: $\underline{\text { http://healthindisasters.com/images/Books/Systematic-Review-Resource-Package. }}$ pdf [accessed 2016-08-28]

78. Academy of Nutrition and Dietetics. Evidence Analysis Manual: Steps in the Academy Evidence Analysis Process. Academy of Nutrition and Dietetics. Chicago: Evidence Analysis Library; 2016 Apr. URL: https://www.andeal.org/ evidence-analysis-manual [accessed 2020-08-18]

79. Salmond SW. Steps in the systematic review process. In: Holly C, Salmond SW, Saimbert MK, editors. Comprehensive systematic review for advanced nursing practice. New York: Springer; 2012:13-32.

80. Deitz DK, Cook RF, Billings DW, Hendrickson A. A web-based mental health program: reaching parents at work. J Pediatr Psychol 2009 Jun;34(5):488-494 [FREE Full text] [doi: 10.1093/jpepsy/jsn108] [Medline: 18845585]

81. Choi H, Kim S, Ko H, Kim Y, Park CG. Development and preliminary evaluation of culturally specific web-based intervention for parents of adolescents. J. Psychiatr. Ment. Health Nurs 2016 Aug 08;23(8):489-501. [doi: 10.1111/jpm.12327]

82. Molleda L, Bahamon M, St George SM, Perrino T, Estrada Y, Correa Herrera D, et al. Clinic Personnel, Facilitator, and Parent Perspectives of eHealth Familias Unidas in Primary Care. J Pediatr Health Care 2017 May;31(3):350-361 [FREE Full text] [doi: 10.1016/j.pedhc.2016.11.001] [Medline: 28012799]

83. Estrada Y, Molleda L, Murray A, Drumhiller K, Tapia M, Sardinas K, et al. eHealth Familias Unidas: Pilot Study of an Internet Adaptation of an Evidence-Based Family Intervention to Reduce Drug Use and Sexual Risk Behaviors Among Hispanic Adolescents. IJERPH 2017 Mar 04;14(3):264. [doi: 10.3390/ijerph14030264]

84. Harden A, Thomas J, Cargo M, Harris J, Pantoja T, Flemming K, et al. Cochrane Qualitative and Implementation Methods Group guidance series-paper 5: methods for integrating qualitative and implementation evidence within intervention effectiveness reviews. J Clin Epidemiol 2018 May;97:70-78. [doi: 10.1016/j.jclinepi.2017.11.029] [Medline: 29242095]

85. Sandelowski M, Leeman J, Knafl K, Crandell JL. Text-in-context: a method for extracting findings in mixed-methods mixed research synthesis studies. J Adv Nurs 2012 Aug 27;69(6):1428-1437. [doi: 10.1111/jan.12000]

86. Thomas J, Harden A, Newman M. Synthesis: combining results systematically and appropriately. In: Gough D, Oliver S, Thomas J, editors. An introduction to Systematic Reviews. London: SAGE; 2012:66-82. 
87. Taherdoost H. A review of technology acceptance and adoption models and theories. Procedia Manufacturing 2018;22:960-967. [doi: 10.1016/j.promfg.2018.03.137]

88. Brinkel J, Dako-Gyeke P, Krämer A, May J, Fobil J. An investigation of users' attitudes, requirements and willingness to use mobile phone-based interactive voice response systems for seeking healthcare in Ghana: a qualitative study. Public Health 2017 Mar;144:125-133. [doi: 10.1016/j.puhe.2016.11.017]

89. Oldenburg B, Taylor CB, O'Neil A, Cocker F, Cameron LD. Using New Technologies to Improve the Prevention and Management of Chronic Conditions in Populations. Annu. Rev. Public Health 2015 Mar 18;36(1):483-505. [doi: 10.1146/annurev-publhealth-031914-122848]

90. Christodoulakis C, Asgarian A, Easterbrook S. Barriers to Adoption of Information Technology in Healthcare. In: Proceedings of the 27th Annual International Conference on Computer Science and Software Engineering. 2017 Nov Presented at: ACM CASCON Conference; 2017; Toronto p. 66-75. [doi: 10.4018/978-1-60566-988-5.ch009]

91. Park E, Kim H, Steinhoff A. Health-related internet use by informal caregivers of children and adolescents: An integrative literature review. J Med Internet Res 2016;18(3):1-10. [doi: 10.2196/jmir.4124]

92. Celebic G, Rendulic D. Basic Concepts of Information and Communication Technology. Handbook. Zagreb: Open Society for Idea Exchange (ODRAZI); 2011:1-39.

93. David L. Introduction to information and communication technologies. Module 1. In: Large JA, editor. ICT for Library and Information Professionals: A Training package for Developing Countries. Bangkok: UNESCO; 2001:1-192.

94. Schneider S. Information and Communication Technologies in Public Child Welfare: A Systematic Literature Review. Master thesis. San Bernardino: California State University; 2017 Jun. URL: http://scholarworks.lib.csusb.edu/etd/473 [accessed 2018-03-22]

95. Glascoe FP, Trimm F. Brief approaches to developmental-behavioral promotion in primary care: updates on methods and technology. Pediatrics 2014 May;133(5):884-897 [FREE Full text] [doi: 10.1542/peds.2013-1859] [Medline: 24777220]

96. Sander L, Rausch L, Baumeister H. Effectiveness of Internet-Based Interventions for the Prevention of Mental Disorders: A Systematic Review and Meta-Analysis. JMIR Ment Health 2016 Aug 17;3(3):e38. [doi: 10.2196/mental.6061]

97. Mitchell SJ, Godoy L, Shabazz K, Horn IB. Internet and Mobile Technology Use Among Urban African American Parents: Survey Study of a Clinical Population. J Med Internet Res 2014 Jan 13;16(1):e9. [doi: 10.2196/jmir.2673]

98. Heynsbergh N, Heckel L, Botti M, Livingston PM. Feasibility, useability and acceptability of technology-based interventions for informal cancer carers: a systematic review. BMC Cancer 2018 Mar 2;18(1). [doi: 10.1186/s12885-018-4160-9]

99. Nieuwboer CC, Fukkink RG, Hermanns JM. Online programs as tools to improve parenting: A meta-analytic review. Children and Youth Services Review 2013 Nov;35(11):1823-1829. [doi: 10.1016/j.childyouth.2013.08.008]

100. Knapp C, Madden V, Wang H, Sloyer P, Shenkman E. Internet Use and eHealth Literacy of Low-Income Parents Whose Children Have Special Health Care Needs. J Med Internet Res 2011 Sep 29;13(3):e75. [doi: 10.2196/jmir.1697]

101. Pivec F. The global information technology report 2003-2004. OZ 2003;8(4):203-206. [doi: 10.3359/oz0304203]

102. Riley W. Theoretical models to inform technology-based health behavior interventions. In: Marsch LA, Lord SE, Dallery J, editors. Behavioral healthcare and technology. Using Science-based innovations to transform practice. New York: Oxfords University Press; 2015.

103. Naslund JA, Aschbrenner KA, Araya R, Marsch LA, Unützer J, Patel V, et al. Digital technology for treating and preventing mental disorders in low-income and middle-income countries: a narrative review of the literature. The Lancet Psychiatry 2017 Jun;4(6):486-500. [doi: 10.1016/s2215-0366(17)30096-2]

104. Galan-Caridad JM, Harel S, Arenzana TL, Hou ZE, Doetsch FK, Mirny LA, et al. Zfx controls the self-renewal of embryonic and hematopoietic stem cells. Cell 2007 Apr 20;129(2):345-357 [FREE Full text] [doi: 10.1016/j.cell.2007.03.014] [Medline: 17448993]

105. Sprague K, Manyika J, Chappuis B, Bughin J, Grijpink F, Moodley L. Offline and falling behind: Barriers to Internet adoption. Technology, Media, and Telecom Practice.: McKinsey \& Company; 2014 Oct. URL: https://www.mckinsey.com/ industries/technology-media-and-telecommunications/our-insights/offline-and-falling-behind-barriers-to-internet-adoption\# [accessed 2018-10-31]

106. Domek GJ, Contreras-Roldan IL, Asturias EJ, Bronsert M, Bolaños Ventura GA, O'Leary ST, et al. Characteristics of mobile phone access and usage in rural and urban Guatemala: assessing feasibility of text message reminders to increase childhood immunizations. Mhealth 2018 Apr;4:9 [FREE Full text] [doi: 10.21037/mhealth.2018.03.05] [Medline: 29780812]

107. Anderson-Lewis C, Darville G, Mercado RE, Howell S, Di Maggio S. mHealth Technology Use and Implications in Historically Underserved and Minority Populations in the United States: Systematic Literature Review. JMIR Mhealth Uhealth 2018 Jun 18;6(6):e128. [doi: 10.2196/mhealth.8383]

108. Chacko A, Isham A, Cleek AF, McKay MM. Using mobile health technology to improve behavioral skill implementation through homework in evidence-based parenting intervention for disruptive behavior disorders in youth: study protocol for intervention development and evaluation. Pilot Feasibility Stud 2016 Sep;2:57 [FREE Full text] [doi: 10.1186/s40814-016-0097-4] [Medline: 27965873]

109. Breitenstein SM, Gross D, Christophersen R. Digital Delivery Methods of Parenting Training Interventions: A Systematic Review. Worldviews on Evidence-Based Nursing 2014 May 19;11(3):168-176. [doi: 10.1111/wvn.12040] 
110. DeHoff BA, Staten LK, Rodgers RC, Denne SC. The Role of Online Social Support in Supporting and Educating Parents of Young Children With Special Health Care Needs in the United States: A Scoping Review. J Med Internet Res 2016 Dec 22;18(12):e333. [doi: 10.2196/jmir.6722]

111. Francomano JA, Harpin SB. Utilizing Social Networking Sites to Promote Adolescents' Health. CIN: Computers, Informatics, Nursing 2015;33(1):10-20. [doi: 10.1097/cin.0000000000000113]

112. Catalano D, Holloway L, Mpofu E. Mental Health Interventions for Parent Carers of Children with Autistic Spectrum Disorder: Practice Guidelines from a Critical Interpretive Synthesis (CIS) Systematic Review. IJERPH 2018 Feb 14;15(2):341. [doi: 10.3390/ijerph15020341]

113. Gavazzi S. Web-based resources on family programs. In: Levesque R, editor. Families with adolescents. Bridging the gaps between theory, research, and practice. New York: Springer USA; 2011:134.

114. Rimer B, Kreuter M. Advancing tailored health communication: A persuasion and message effects perspective. Journal of Communication 2006;56:S184-S201. [doi: 10.1111/j.1460-2466.2006.00289.x]

115. Rexhaj S, Leclerc C, Bonsack C, Golay P, Favrod J. Feasibility and Accessibility of a Tailored Intervention for Informal Caregivers of People with Severe Psychiatric Disorders: a Pilot Study. Front. Psychiatry 2017 Sep 21;8. [doi: 10.3389/fpsyt.2017.00178]

116. Fernandes CS, Angelo M. Family caregivers: what do they need? An integrative review. Rev. esc. enferm. USP 2016 Aug;50(4):675-682. [doi: 10.1590/s0080-623420160000500019]

117. Frauenholtz S, Conrad-Hiebner A, Mendenhall AN. Children's Mental Health Providers' Perceptions of Mental Health Literacy Among Parents and Caregivers. Journal of Family Social Work 2015 Jan 22;18(1):40-56. [doi: $\underline{10.1080 / 10522158.2014 .974116]}$

118. Mendenhall E, De Silva MJ, Hanlon C, Petersen I, Shidhaye R, Jordans M, et al. Acceptability and feasibility of using non-specialist health workers to deliver mental health care: stakeholder perceptions from the PRIME district sites in Ethiopia, India, Nepal, South Africa, and Uganda. Soc Sci Med 2014 Oct;118:33-42 [FREE Full text] [doi:

10.1016/j.socscimed.2014.07.057] [Medline: 25089962]

119. Wozney L, Radomski AD, Newton AS. The Gobbledygook in Online Parent-Focused Information about Child and Adolescent Mental Health. Health Communication 2017 Apr 12;33(6):710-715. [doi: 10.1080/10410236.2017.1306475]

120. Ploeg J, Markle-Reid M, Valaitis R, McAiney C, Duggleby W, Bartholomew A, et al. Web-Based Interventions to Improve Mental Health, General Caregiving Outcomes, and General Health for Informal Caregivers of Adults With Chronic Conditions Living in the Community: Rapid Evidence Review. J Med Internet Res 2017 Jul 28;19(7):e263. [doi: 10.2196/jmir.7564]

121. Garcia-Huidobro D, Diaspro-Higuera MO, Palma D, Palma R, Ortega L, Shlafer R, et al. Adaptive Recruitment and Parenting Interventions for Immigrant Latino Families with Adolescents. Prev Sci 2018 Apr 11. [doi: 10.1007/s11121-018-0898-1] [Medline: 29644545]

122. McNabb DE, Gibson LK, Finnie BW. The Case of the Vanishing Workforce. Public Performance \& Management Review 2006 Mar 1;29(3):358-368. [doi: 10.2753/PMR1530-9576290306]

123. Sajedi F, Habibi E, Shahshahanipour S, Hatamizadeh N. An Approach towards Promoting Iranian Caregivers' Knowledge on Early Childhood Development. Int J Pediatr 2018 Mar;6(3):7371-7382. [doi: 10.22038/ijp.2017.27419.2364]

124. Dumka LE, Gonzales NA, Wheeler LA, Millsap RE. Parenting self-efficacy and parenting practices over time in Mexican American families. Journal of Family Psychology 2010;24(5):522-531. [doi: 10.1037/a0020833]

125. Knight K, Hunter C. Using technology in service delivery to families, children and young people. Child Family Community Australia. Melbourne: Australian Institute of Family Studies; 2013 Oct. URL: https://aifs.gov.au/cfca/publications/ using-technology-service-delivery-families-children-and-young-people [accessed 2018-10-20]

126. Onwumere J, Kuipers E. Caregiving roles: when will they be routinely recognized and supported? Journal of Mental Health 2017 Mar 29;26(2):95-97. [doi: 10.1080/09638237.2017.1301649]

127. Jaccard J, Levitz N. Parent-based interventions to reduce adolescent problem behaviors: New directions for self-regulation approaches. In: Oettingen G, Gollwitzer P, editors. Self-Regulation Adolescence. New York: Cambridge University Press; 2013:357-388.

128. Dunst C. Parent Involvement in Early Childhood Intervention: Characteristics of family capacity-building practices. In: 7th Annual Conference on Meeting the Therapy Needs of Infants, Toddlers and Children with Disabilities in Rural Communities. 2016 Mar 12 Presented at: 7th Annual Conference on meeting the Therapy needs of infants, toddlers and children with disabiities in rural communities; 2016; Lexington p. 1-38. [doi: 10.4324/9781315688442]

129. Yzer M. The Integrative Model of Behavioral Prediction as a Tool for Designing Health Messages: Theory and Practice. In: Cho H, editor. Designing Messages for Health Communication Campaigns. Thousand Oaks: SAGE; 2012:21-40.

130. Hall CM, Bierman KL. Technology-assisted interventions for parents of young children: Emerging practices, current research, and future directions. Early Childhood Research Quarterly 2015;33:21-32. [doi: 10.1016/j.ecresq.2015.05.003]
Abbreviations
eHealth: electronic health
IMBP: Integrated Model of Behavior Prediction 
mHealth: mobile health

PICO: population, intervention, comparison intervention, outcome

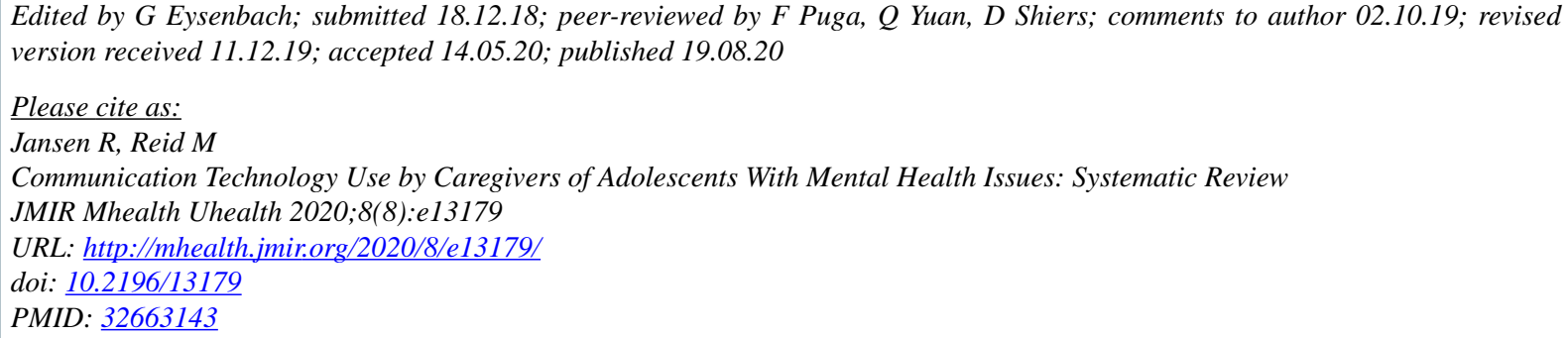

CRonelle Jansen, Marianne Reid. Originally published in JMIR mHealth and uHealth (http://mhealth.jmir.org), 19.08.2020. This is an open-access article distributed under the terms of the Creative Commons Attribution License (https://creativecommons.org/licenses/by/4.0/), which permits unrestricted use, distribution, and reproduction in any medium, provided the original work, first published in JMIR mHealth and uHealth, is properly cited. The complete bibliographic information, a link to the original publication on http://mhealth.jmir.org/, as well as this copyright and license information must be included. 